\title{
Nitrous oxide production associated with coastal marine invertebrates
}

\author{
Ines Maria Heisterkamp ${ }^{1, *}$, Andreas Schramm ${ }^{2}$, Dirk de Beer ${ }^{1}$, Peter Stief ${ }^{1}$ \\ ${ }^{1}$ Max Planck Institute for Marine Microbiology, Microsensor Group, Celsiusstraße 1, 28359 Bremen, Germany \\ ${ }^{2}$ Department of Biological Sciences, Microbiology, Aarhus University, Ny Munkegade 114, 8000 Aarhus C, Denmark
}

\begin{abstract}
Several freshwater and terrestrial invertebrate species emit the greenhouse gas nitrous oxide $\left(\mathrm{N}_{2} \mathrm{O}\right)$. The $\mathrm{N}_{2} \mathrm{O}$ production associated with these animals was ascribed to incomplete denitrification by ingested sediment or soil bacteria. The present study shows that many marine invertebrates also emit $\mathrm{N}_{2} \mathrm{O}$ at substantial rates. A total of 19 invertebrate species collected in the German Wadden Sea and in Aarhus Bay, Denmark, and 1 aquacultured shrimp species were tested for $\mathrm{N}_{2} \mathrm{O}$ emission. Potential $\mathrm{N}_{2} \mathrm{O}$ emission rates ranged from 0 to $1.354 \mathrm{nmol}$ ind. ${ }^{-1} \mathrm{~h}^{-1}$, with an average rate of $0.320 \mathrm{nmol}$ ind. $^{-1} \mathrm{~h}^{-1}$, excluding the aquacultured shrimp Litopenaeus vannamei, which showed the highest rate of $\mathrm{N}_{2} \mathrm{O}$ emission measured so far for any marine species (3.569 nmol ind. ${ }^{-1} \mathrm{~h}^{-1}$ ), probably due to very high nitrate concentrations in the rearing tanks. The $\mathrm{N}_{2} \mathrm{O}$ emitted by $L$. vannamei was almost exclusively produced in its gut by incomplete denitrification. Statistical analysis revealed that body weight, habitat, and exoskeletal biofilms were important determinants of animal-associated $\mathrm{N}_{2} \mathrm{O}$ production. The snail Hinia reticulata emitted about 3.5 times more $\mathrm{N}_{2} \mathrm{O}$ with an intact exoskeletal biofilm on its shell than with an experimentally cleaned shell. Thus, the $\mathrm{N}_{2} \mathrm{O}$ production associated with marine invertebrates is apparently not due to gut denitrification in every species, but may also result from microbial activity on the external surfaces of animals. The high abundance and potential $\mathrm{N}_{2} \mathrm{O}$ emission rates of many marine invertebrate species suggest significant contributions to overall $\mathrm{N}_{2} \mathrm{O}$ emissions from coastal marine environments and aquaculture facilities.
\end{abstract}

KEY WORDS: Marine invertebrate $\cdot$ Animal-microbe interaction · Gut microbiology - Exoskeletal biofilm · Coastal marine ecosystem $\cdot$ Aquaculture

Resale or republication not permitted without written consent of the publisher

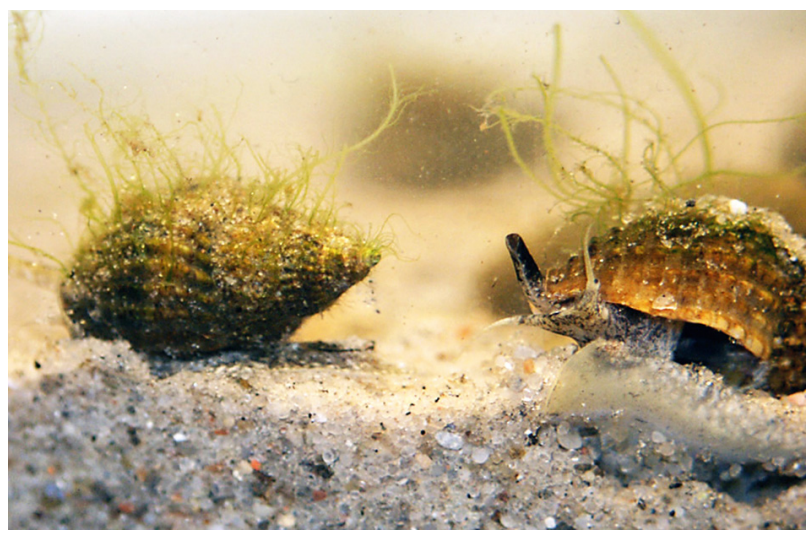

$\mathrm{N}_{2} \mathrm{O}$ production associated with the snail Hinia reticulata partly results from microbial activity in exoskeletal biofilms covering the shell.

Photo: I. M. Heisterkamp

\section{INTRODUCTION}

Nitrous oxide $\left(\mathrm{N}_{2} \mathrm{O}\right)$ is the third most important greenhouse gas after carbon dioxide and methane. Its atmospheric concentration is rapidly increasing, and it contributes significantly to global warming (IPCC 2007) and to the depletion of the stratospheric ozone layer (Ravishankara et al. 2009). Biogenic $\mathrm{N}_{2} \mathrm{O}$ emission originates primarily from soils and oceans, where microbial nitrification and denitrification are the major $\mathrm{N}_{2} \mathrm{O}$-producing processes (Mosier et al. 1998, Stein \& Yung 2003). During nitrification (the 2-stage oxidation of ammonium to nitrate) $\mathrm{N}_{2} \mathrm{O}$ is produced as a byproduct in the first oxidation step (Goreau et al. 1980), whereas in denitrification (the respiratory reduction of nitrate or nitrite to nitrogenous gases) $\mathrm{N}_{2} \mathrm{O}$ is produced 
as a true intermediate (Zumft 1997). The complete denitrification pathway involves 4 enzymes that reduce nitrate to dinitrogen stepwise via the intermediates nitrite, nitric oxide, and $\mathrm{N}_{2} \mathrm{O}$. The 4 reductases are induced sequentially under anoxic conditions when oxidized inorganic nitrogen compounds and appropriate electron donors are available (Tiedje 1988, Zumft 1997). Whether denitrification acts as a source or sink of $\mathrm{N}_{2} \mathrm{O}$ depends on the presence and activity of nitrous oxide reductase, which shows a higher sensitivity towards oxygen, lower carbon-to-nitrate ratios, and lower $\mathrm{pH}$ than the other 3 enzymes (Tiedje 1988, Bonin \& Raymond 1990).

Important sites of $\mathrm{N}_{2} \mathrm{O}$ emission are environments that are characterized by high input and turnover rates of inorganic nitrogen, such as fertilized soils and coastal areas (Mosier et al. 1998, Seitzinger \& Kroeze 1998, Bange 2006). Microbial nitrogen conversions and concomitant $\mathrm{N}_{2} \mathrm{O}$ production are especially stimulated in coastal sediments and in rock biofilms, due to high riverine input of nitrogen (Seitzinger \& Nixon 1985, Law et al. 1992, Middelburg et al. 1995, Robinson et al. 1998, Magalhaes et al. 2005). Nitrification activity prevails at the oxic sediment surface and is fuelled by ammonium from organic matter degradation. Denitrification activity prevails in the anoxic subsurface layer and is driven by nitrate from nitrification (i.e. coupled nitrification-denitrification) or the water column (Jenkins \& Kemp 1984). Sedimentary denitrification is commonly assumed to be the major source of $\mathrm{N}_{2} \mathrm{O}$ to the water column, with benthic $\mathrm{N}_{2} \mathrm{O}$ fluxes making up approximately $1 \%$ of the dinitrogen fluxes (Seitzinger 1988, Magalhaes et al. 2007, Ferrón et al. 2009). Sedimentary nitrification can, despite lower $\mathrm{N}_{2} \mathrm{O}$ production rates, significantly contribute to benthic $\mathrm{N}_{2} \mathrm{O}$ fluxes, due to its proximity to the sediment surface (Meyer et al. 2008). Oversaturation of $\mathrm{N}_{2} \mathrm{O}$ in the water column occurs in many coastal areas (Kieskamp et al. 1991, Middelburg et al. 1995, Robinson et al. 1998, Dong et al. 2002).

Besides the microbial $\mathrm{N}_{2} \mathrm{O}$ production in soils, sediments, and water bodies, $\mathrm{N}_{2} \mathrm{O}$ is also emitted by earthworms and freshwater invertebrates (Karsten \& Drake 1997, Drake \& Horn 2007, Stief et al. 2009). This animal-associated $\mathrm{N}_{2} \mathrm{O}$ production is due to the denitrification activity of ingested bacteria in the anoxic gut. The specific in situ conditions of the earthworm gut, including anoxia and high concentrations of easily degradable organic carbon, as well as nitrate or nitrite, stimulate the activity of ingested $\mathrm{N}_{2} \mathrm{O}$-producing soil bacteria (Drake et al. 2006). A similar mechanism has been suggested for freshwater invertebrates, whose $\mathrm{N}_{2} \mathrm{O}$ emission is largely explained by their preferred diet: filter- and deposit-feeders show high, shredders and grazers intermediate, and predators very low $\mathrm{N}_{2} \mathrm{O}$ emission rates (Stief et al. 2009). This suggests that $\mathrm{N}_{2} \mathrm{O}$ emission is caused by bacteria that are coingested with the food taken up by freshwater invertebrates. $\mathrm{N}_{2} \mathrm{O}$ emission rates of both terrestrial and freshwater invertebrates increase with nitrate and temperature and decrease with oxygen availability, indicating the important role of these environmental factors for gut denitrification (Karsten \& Drake 1997, Matthies et al. 1999, Stief et al. 2009, 2010, Stief \& Schramm 2010).

The $\mathrm{N}_{2} \mathrm{O}$ emission potential of marine invertebrates has so far been neglected, although coastal marine sediments are presumably hot spots of $\mathrm{N}_{2} \mathrm{O}$ emission, since they are densely inhabited by filter- and depositfeeding invertebrates (Williams et al. 2004, Philippart et al. 2007) and exposed to high nitrate concentrations (Kieskamp et al. 1991, Van Beusekom et al. 2008). High $\mathrm{N}_{2} \mathrm{O}$ emission can also be expected from aquaculture facilities in which animals are typically reared at high densities and high nitrate concentrations. The present study, therefore, investigated the $\mathrm{N}_{2} \mathrm{O}$ emission potential of different marine invertebrate species from coastal sediments of the North Sea and Baltic Sea and of the aquacultured shrimp Litopenaeus vannamei. To understand how the $\mathrm{N}_{2} \mathrm{O}$ emission potential of marine invertebrates is controlled by abiotic and biotic factors, correlations between potential $\mathrm{N}_{2} \mathrm{O}$ emission rates and species-specific traits were investigated by statistical analysis.

\section{MATERIALS AND METHODS}

Sampling of animals. We tested the $\mathrm{N}_{2} \mathrm{O}$ emission potential of 19 benthic invertebrate species from the German Wadden Sea and Aarhus Bay in Denmark, and of the aquacultured shrimp Litopenaeus vannamei (provided by Ecomaris Marifarm Kiel, Germany). Sampling was carried out between March and June 2008 at the mixed sediment intertidal flat near Dorum-Neufeld $\left(53^{\circ} 45^{\prime} \mathrm{N}, 8^{\circ} 21^{\prime} \mathrm{E}\right)$ and at 3 different sites in Aarhus Bay $\left(56^{\circ} 9.75^{\prime} \mathrm{N}, 10^{\circ} 16.80^{\prime} \mathrm{E}\right.$; $56^{\circ} 9.29^{\prime} \mathrm{N}, 10^{\circ} 19.15^{\prime} \mathrm{E}$; $\left.56^{\circ} 6.44^{\prime} \mathrm{N}, 10^{\circ} 27.96^{\prime} \mathrm{E}\right)$. Animals from the Wadden Sea were sampled at low tide. Epifaunal species were collected by forceps or hand, and infaunal species by digging up the sediment with a spade to a depth of approximately $25 \mathrm{~cm}$ and searching it by hand. Animals were placed in beakers filled with a layer of wet sediment from the sampling site until further processing in the laboratory. Sampling in Aarhus Bay was carried out from a research vessel by dredging the sediment with a triangle net. Some animals such as shore crabs and ascidians were sampled from rocks or pontoons in the harbor area of Aarhus. Sampled animals were kept in buckets filled with seawater from 
the upper water column $\left(15^{\circ} \mathrm{C}\right)$ until incubation in the laboratory was started. The temperature of the water was measured at each sampling site, and water samples were filtered $(0.2 \mu \mathrm{m})$ and stored at $-20^{\circ} \mathrm{C}$ until nitrate concentration was measured using the $\mathrm{VCl}_{3}$ reduction method (Braman \& Hendrix 1989) with a chemiluminescence detector (CLD $66 \quad \mathrm{~S} \quad \mathrm{NO} / \mathrm{NO}_{\mathrm{X}}{ }^{-}$ Analyser, Eco Physics).

Classification of species. The screening included Crustacea, Mollusca, Echinodermata, Polychaeta, and Ascidia (Table 1). For each species, the affiliation to a feeding type and to a benthic habitat was determined (Table 1). Species that feed by several feeding modes were assigned to their dominant feeding mode. The description 'infaunal + epifaunal' refers to infaunal species that feed at the sediment surface or in the water column. Species were further characterized by their wet weight and by the presence/absence of a visible microbial biofilm on exoskeletal surfaces such as molluscan shells, crustacean exoskeletons and shell plates of polychaetes (Table 1). Most species with sturdy external surfaces carried such exoskeletal biofilms, but some of the crustacean and molluscan species (i.e. Corophium volutator, Pagurus bernhardus and Litopenaeus vannamei, Macoma balthica, Scrobicularia plana, Cerastoderma edule) did not.

Rate of $\mathrm{N}_{2} \mathrm{O}$ emission. $\mathrm{N}_{2} \mathrm{O}$ emission of the specimens was determined by incubating freshly collected, living animals (exception: Litopenaeus vannamei) in gas-tight vials with septa that allowed repeated sampling of the headspace for $\mathrm{N}_{2} \mathrm{O}$. The incubations were standardized regarding temperature $\left(21^{\circ} \mathrm{C}\right)$ and oxygen (initially oxic headspace), since the main goal of the screening was to search for species-specific rather than environmental controls of $\mathrm{N}_{2} \mathrm{O}$ emission. In many cases, the standardized conditions in the incubation vial were different from those in the natural habitat of the animals. Therefore, the $\mathrm{N}_{2} \mathrm{O}$ emission rates measured with this approach represent potential rather than actual or in situ rates.

Incubation of animals was started after sampling, transport, and preparation of incubation vials, which

Table 1. List of taxa tested for $\mathrm{N}_{2} \mathrm{O}$ emission with sampling details (temperature and nitrate concentration in the overlaying water column at the sampling site). Taxa are sorted by descending weight within each taxonomic group. Sampling sites-AB: Aarhus Bay; WS: Wadden Sea; AQ: aquaculture; Feeding types-C: carnivore; DF: deposit-feeder; FF: filter-feeder; G: grazer. Habitat_E: epifaunal; I: infaunal; EI: epifaunal + infaunal

\begin{tabular}{|c|c|c|c|c|c|c|c|}
\hline Species & Site & $\begin{array}{l}\text { Temp. } \\
\left({ }^{\circ} \mathrm{C}\right)\end{array}$ & $\begin{array}{l}\text { Nitrate } \\
(\mu \mathrm{M})\end{array}$ & $\begin{array}{l}\text { Wet weight } \\
(\mathrm{g})\end{array}$ & $\begin{array}{l}\text { Feeding } \\
\text { type }\end{array}$ & Habitat & $\begin{array}{c}\text { Exoskeletal } \\
\text { biofilm }\end{array}$ \\
\hline \multicolumn{8}{|l|}{ Ascidia } \\
\hline Ascidia sp. & $\mathrm{AB}$ & 16 & $0-4$ & 7.18 & $\mathrm{FF}$ & $\mathrm{E}$ & Yes \\
\hline \multicolumn{8}{|l|}{ Crustacea } \\
\hline Carcinus maenas & $\mathrm{AB}$ & 15 & $0-4$ & 2.95 & $\mathrm{C}$ & $\mathrm{E}$ & Yes \\
\hline Pagurus bernhardus & $\mathrm{AB}$ & 7 & $0-4$ & 2.81 & $\mathrm{C}$ & $\mathrm{E}$ & No \\
\hline Corophium volutator & WS & 8 & 20 & 0.01 & $\mathrm{DF}$ & EI & No \\
\hline \multicolumn{8}{|l|}{ Echinodermata } \\
\hline Echinocyamus pusillus & $\mathrm{AB}$ & 7 & $0-4$ & 0.71 & DF & I & No \\
\hline Echinocardium cordatum & $\mathrm{AB}$ & 7 & $0-4$ & 0.27 & $\mathrm{DF}$ & I & No \\
\hline \multicolumn{8}{|l|}{ Mollusca } \\
\hline Scrobicularia plana & WS & 15 & 20 & 4.63 & DF & EI & No \\
\hline Cerastoderma edule & WS & 15 & 20 & 2.07 & $\mathrm{FF}$ & EI & No \\
\hline Mytilus edulis & $\mathrm{AB}$ & 7 & $0-4$ & 0.97 & FF & $\mathrm{E}$ & Yes \\
\hline Macoma balthica & WS & 15 & 20 & 0.31 & $\mathrm{DF}$ & EI & No \\
\hline Polyplacophora $^{\mathrm{a}}$ & $\mathrm{AB}$ & 7 & $0-4$ & 0.27 & $\mathrm{G}$ & $\mathrm{E}$ & Yes \\
\hline Littorina littorea & WS & 22 & 20 & 2.22 & G & $\mathrm{E}$ & Yes \\
\hline Hinia reticulata & $\mathrm{AB}$ & 7 & $0-4$ & 1.70 & $\mathrm{C}$ & EI & Yes \\
\hline Gibbula sp. & $\mathrm{AB}$ & 7 & $0-4$ & 0.78 & $\mathrm{G}$ & $\mathrm{E}$ & Yes \\
\hline Hydrobia ulvae & WS & 21 & 20 & 0.01 & G & $\mathrm{E}$ & Yes \\
\hline \multicolumn{8}{|l|}{ Polychaeta } \\
\hline Arenicola marina & WS & 8 & 20 & 2.06 & DF & $\mathrm{I}$ & No \\
\hline Lepidonotus squamatus & $\mathrm{AB}$ & 7 & $0-4$ & 0.49 & $\mathrm{C}$ & $\mathrm{E}$ & Yes \\
\hline Nephtys hombergii & WS & 8 & 20 & 0.33 & $\mathrm{C}$ & $\mathrm{I}$ & No \\
\hline Nereis diversicolor & WS & 8 & 20 & 0.15 & $\mathrm{DF}$ & EI & No \\
\hline \multicolumn{8}{|l|}{ Crustacea } \\
\hline Litopenaeus vannamei & $\mathrm{AQ}$ & $28-30$ & 1000 & 21.16 & DF & $\mathrm{E}$ & No \\
\hline${ }^{a}$ Not determined to genus 1 & & & & & & & \\
\hline
\end{tabular}


Table 2. Potential $\mathrm{N}_{2} \mathrm{O}$ emission rates per $\mathrm{g}$ wet wt (mean $\pm \mathrm{SD}$ for $\mathrm{N} \geq 3$; mean and range for $\mathrm{N}=2$ ) of the 20 tested species. $\mathrm{N}$ : number of replicates per species (ind. per incubation vial). Initial and highest $\mathrm{N}_{2} \mathrm{O}$ concentration in the incubation vial

\begin{tabular}{|c|c|c|c|c|}
\hline \multirow[t]{2}{*}{ Species } & \multirow{2}{*}{$\begin{array}{l}\mathrm{N}_{2} \mathrm{O} \text { emission } \\
\left(\mathrm{nmol} \mathrm{g}^{-1} \mathrm{~h}^{-1}\right)\end{array}$} & \multirow{2}{*}{$\begin{array}{c}\mathrm{N} \\
\text { (range) }\end{array}$} & \multicolumn{2}{|c|}{$\mathrm{N}_{2} \mathrm{O}$ conc. $(\mathrm{nM})$} \\
\hline & & & Initial & Highest \\
\hline Ascidia sp. & $0.043 \pm 0.024$ & $5(1-4)$ & 5.9 & 54 \\
\hline Carcinus maenas & $0.369 \pm 0.137$ & $3(1-3)$ & 12.5 & 311 \\
\hline Pagurus bernhardus & $0.020 \pm 0.018$ & $5(1-3)$ & 8.5 & 167 \\
\hline Corophium volutator & $0.955 \pm 0.664$ & $2(6-7)$ & 10.2 & 123 \\
\hline Echinocyamus pusillus & $0.040 \pm 0.027$ & $3(1-3)$ & 12.7 & 40 \\
\hline Echinocardium cordatum & 0.069 & $1(5)$ & 12.2 & 20 \\
\hline Scrobicularia plana & $0.302 \pm 0.083$ & $3(2-3)$ & 9.2 & 263 \\
\hline Cerastoderma edule & 0.126 & $1(5)$ & 9.5 & 187 \\
\hline Mytilus edulis & $0.269 \pm 0.280$ & $7(1)$ & 10.2 & 264 \\
\hline Macoma balthica & $1.098 \pm 1.066$ & $7(4-30)$ & 9.8 & 287 \\
\hline Polyplacophora $^{a}$ & $0.471 \pm 0.237$ & $2(6)$ & 12.5 & 465 \\
\hline Littorina littorea & $0.237 \pm 0.208$ & $6(5-15)$ & 9.7 & 167 \\
\hline Hinia reticulata & $0.608 \pm 0.265$ & $7(1-3)$ & 13.1 & 542 \\
\hline Gibbula sp. & $0.107 \pm 0.037$ & $2(2-4)$ & 13.1 & 345 \\
\hline Hydrobia ulvae & $5.449 \pm 1.822$ & $4(25-50)$ & 10.7 & 463 \\
\hline Arenicola marina & $0.045 \pm 0.032$ & $3(1-2)$ & 11.3 & 55 \\
\hline Lepidonotus squamatus & 0.666 & $1(3)$ & 12.5 & 466 \\
\hline Nephtys hombergii & $0.082 \pm 0.053$ & $3(1-2)$ & 0.1 & 5.6 \\
\hline Nereis diversicolor & $0.398 \pm 0.319$ & $9(1-2)$ & 11.7 & 21 \\
\hline Litopenaeus vannamei & $0.183 \pm 0.066$ & $6(1)$ & 12.5 & 250 \\
\hline
\end{tabular}

Animals were cleaned of loosely attached sediment and algal tufts by washing them in autoclaved seawater and drying them on paper tissue; the tightly attached biofilms largely remained on the external surface of the animals. To explicitly test for effects of this exoskeletal biofilm on the $\mathrm{N}_{2} \mathrm{O}$ emission potential, the snail Hinia reticulata was incubated both with biofilm-covered shells and with shells that were cleaned by thoroughly brushing them with a sterile toothbrush, although cleaning still left residues of biofilm in the grooves of the shell surface.

The accumulation of $\mathrm{N}_{2} \mathrm{O}$ in the incubation vial was followed over a period of 4 to $6 \mathrm{~h}$ by regularly taking gas samples and analyzing them by gas chromatography. Samples from the Wadden Sea were measured with the GC 7890 (Agilent Technologies) with a CP-PoraPLOT Q column, and samples from Aarhus Bay with the GC-8A (Shimadzu) with a Porapak Q column. Both gas chromatographs were equipped with a ${ }^{63} \mathrm{Ni}$ electron capture de-

took from 3 to $5 \mathrm{~h}$. Species were incubated in 3, 6, 10, or $100 \mathrm{ml}$ sterile gas-tight vials, depending on the size and number of individuals. Most species were found in sufficient quantity to prepare several vials with different numbers of individuals (Table 2). Bivalves and ascidians were submerged in seawater to allow the individuals to be active and thereby exchange gases with the incubation vial. To the other species, only a small volume of seawater was added $(0.05$ to $2 \mathrm{ml})$ to maintain a moist atmosphere in the vials. Species from Aarhus Bay were supplied with $0.2 \mu \mathrm{m}$ filtered seawater collected while sampling the animals; species from the intertidal flat were supplied with autoclaved seawater from the same site, collected during high tide and stored in an opaque tank until used for incubations. Animals were thus exposed to in situ nitrate and ammonium concentrations. The ammonium concentration in the incubation vials was initially below the detection limit of $0.5 \mu \mathrm{M}$ and may have increased due to excretion of ammonium by the animals, which was in the range from 0.1 to $1.0 \mu \mathrm{mol}$ ind..$^{-1} \mathrm{~h}^{-1}$ (I. M. Heisterkamp unpubl. data). The shrimp Litopenaeus vannamei were killed in ice-water before incubating them in $100 \mathrm{ml}$ bottles with $2 \mathrm{ml}$ of $0.2 \mu \mathrm{m}$ filtered aquarium water that contained $1 \mathrm{mM}$ nitrate and $14 \mu \mathrm{M}$ ammonium. Additionally, dissected guts of L. vannamei were incubated in $3 \mathrm{ml}$ exetainers (Labco) supplied with $50 \mu \mathrm{l}$ of $0.2 \mu \mathrm{m}$ filtered aquarium water. tector. Injection volumes were $1 \mathrm{ml}$ for the samples analyzed with the GC 7890 and $0.3 \mathrm{ml}$ for samples analyzed with the GC-8A. After each headspace sampling, the incubation vials were pressure-equilibrated with air by inserting a hypodermic needle through the septum for $1 \mathrm{~s}$. On both GCs, calibration standards were prepared by adding known amounts of $\mathrm{N}_{2} \mathrm{O}$ to $\mathrm{N}_{2}$-flushed gas-tight bottles of known volume and analyzed repeatedly during the incubation. The linear part of the increase of the $\mathrm{N}_{2} \mathrm{O}$ concentration in the incubation vials over time was used to calculate the potential $\mathrm{N}_{2} \mathrm{O}$ emission rate per individual and per biomass. The dilution of the gas phase and the equilibrated distribution of $\mathrm{N}_{2} \mathrm{O}$ between the gas and water phases (Weiss \& Price 1980) were taken into account when calculating the potential $\mathrm{N}_{2} \mathrm{O}$ emission rate. This rate corresponds to the net $\mathrm{N}_{2} \mathrm{O}$ production rate (i.e. gross production less consumption) and thus also depends on $\mathrm{N}_{2} \mathrm{O}$ levels. Since the $\mathrm{N}_{2} \mathrm{O}$ reduction rate was not directly assessed, the initial and final $\mathrm{N}_{2} \mathrm{O}$ concentrations in the incubation vials are reported in Table 2 so that the experiments can be reproduced.

Rate of total denitrification. To determine the potential rate of total denitrification (i.e. production of $\mathrm{N}_{2}+$ $\mathrm{N}_{2} \mathrm{O}$ ) in the shrimp gut, freshly killed Litopenaeus vannamei were dissected and the guts were incubated in an atmosphere of $10 \%$ acetylene and $90 \%$ dinitrogen 
Table 3. Species traits and phenotypes used for statistical analysis of $\mathrm{N}_{2} \mathrm{O}$ emission by marine invertebrates. Phenotypes were sorted according to their hypothesized promotion of $\mathrm{N}_{2} \mathrm{O}$ production (Hypothesis) and then numerically coded (Value)

\begin{tabular}{|lcc|}
\hline $\begin{array}{l}\text { Species trait } \\
\text { Phenotype }\end{array}$ & Hypothesis & Value \\
\hline $\begin{array}{l}\text { Feeding type } \\
\text { Carnivore (predator } \\
\text { + scavenger) }\end{array}$ & $\begin{array}{c}\text { Increasing number } \\
\text { of } \mathrm{N}_{2} \text { O-producing } \\
\text { gut bacteria }\end{array}$ & 0 \\
Gerazer & & 1 \\
Filter-feeder & & 2 \\
Habitat & & 3 \\
Infaunal & Increasing nitrate & \\
Infaunal + epifaunal & availability & 0 \\
Epifaunal & & 1 \\
Exoskeletal biofilm & More biofilm & 2 \\
No & bacteria & 0 \\
Yes & & 1 \\
\hline
\end{tabular}

gas. Acetylene inhibits the last step of denitrification (Sørensen 1978), and thus the accumulation of $\mathrm{N}_{2} \mathrm{O}$ in the incubation vials is indicative of total denitrification. The linear increase of $\mathrm{N}_{2} \mathrm{O}$ concentration in the incubation vials over time was used to calculate the potential total denitrification rate per gut.

Statistical analysis. The potential $\mathrm{N}_{2} \mathrm{O}$ emission rates were tested for correlation with the species traits Feeding type, Habitat, Exoskeletal biofilm, and Weight using the statistical analysis software SPSS. The categories within the species traits Feeding type, Habitat, and Exoskeletal biofilm were ranked according to their hypothesized effects on $\mathrm{N}_{2} \mathrm{O}$ emission rates and were transformed into a numerical code for correlation analysis (Table 3). The hypotheses were that the rate of $\mathrm{N}_{2} \mathrm{O}$ emission is positively correlated to (1) the amount of ingested bacteria, (2) the availability of nitrate, and (3) the presence of a microbial biofilm growing on the external surfaces of the animal. The ranking of the categories was based on the assumptions that (1) the amount of ingested bacteria is determined by the feeding type and increases from carnivores over grazers and deposit-feeders to filter-feeders; (2) the nitrate concentration varies with habitat, being highest in the water column and lowest in the sediment; and (3) the shell and exoskeleton provide colonization surfaces for microbial biofilms. The high rank of filter-feeders regarding the amount of ingested bacteria may be questioned because only a few bivalve species filter unattached bacteria (e.g. Mytilus edulis; McHenery \& Birkbeck 1985). However, species that filter-feed close to the sediment surface, where the concentration of suspended detritus is particularly high, ingest large amounts of attached bacteria (Kach \& Ward 2008).

\section{RESULTS}

The potential $\mathrm{N}_{2} \mathrm{O}$ emission rates of coastal marine invertebrate species ranged from 0 to $1.354 \mathrm{nmol} \mathrm{ind.}^{-1}$ $\mathrm{h}^{-1}$ (Fig. 1), with an average rate of $0.320 \mathrm{nmol}$ ind. ${ }^{-1}$ $\mathrm{h}^{-1}$. The weight-specific emission rates ranged from 0 to $5.448 \mathrm{nmol} \mathrm{g}^{-1} \mathrm{~h}^{-1}$, with an average rate of $0.598 \mathrm{nmol}$ $\mathrm{g}^{-1} \mathrm{~h}^{-1}$ (Table 2). The highest potential $\mathrm{N}_{2} \mathrm{O}$ emission rate of $3.569 \mathrm{nmol}$ ind..$^{-1} \mathrm{~h}^{-1}$ was found for the aquacultured shrimp Litopenaeus vannamei (not included in the above rates) that is exposed to very high nitrate concentrations ( $\geq 1 \mathrm{mM}$ ) and to high temperatures (28 to $30^{\circ} \mathrm{C}$ ) in the rearing tanks (Table 1 ). The $\mathrm{N}_{2} \mathrm{O}$ emission rate of dissected guts of $L$. vannamei was almost as high as the $\mathrm{N}_{2} \mathrm{O}$ emission rate of the whole animal (Fig. 2). Dissected guts showed a total denitrification rate of $12 \mathrm{nmol}$ ind. ${ }^{-1} \mathrm{~h}^{-1}$ under anoxic conditions (Fig. 2).

The nitrate concentrations at the sampling sites in the Wadden Sea and Aarhus Bay were low (0 to $20 \mu \mathrm{M})$, and temperature was 7 to $8^{\circ} \mathrm{C}$ (exception: 15 to $22^{\circ} \mathrm{C}$ at the Wadden Sea site in May 2008; Table 1). The capacity to emit $\mathrm{N}_{2} \mathrm{O}$ occurred across all taxonomic groups and was not restricted to a certain feeding type (Table 1). Most species possessing a shell or exoskeleton had potential $\mathrm{N}_{2} \mathrm{O}$ emission rates higher than the average rates (e.g. the common periwinkle Littorina littorea and the shore crab Carcinus maenas). These conclusions were also true when the rate of $\mathrm{N}_{2} \mathrm{O}$ emission was expressed per gram body weight (Table 2). The potential $\mathrm{N}_{2} \mathrm{O}$ emission rates per individual tended to be higher for larger species than for smaller species (e.g. the bivalves Scrobicularia plana vs. Macoma balthica), while the highest potential $\mathrm{N}_{2} \mathrm{O}$ emission rates per gram body weight were shown by the smallest species (e.g. Hydrobia ulvae, Corophium volutator).

The correlation analysis revealed that the potential $\mathrm{N}_{2} \mathrm{O}$ emission rate per individual was positively correlated with the body weight with a Pearson coefficient of $R=0.506$ ( $p=0.027$ ) for linear correlation and with a Spearman coefficient of $R=0.728$ ( $p<0.001$ ) for non-linear correlation. The species traits Habitat and Exoskeletal biofilm showed positive non-linear correlations with the potential $\mathrm{N}_{2} \mathrm{O}$ emission rate per individual with Spearman coefficients of $\mathrm{R}=0.460$ ( $\mathrm{p}=$ 0.047 ) and $R=0.481$ ( $p=0.037)$, respectively. No correlation between the potential $\mathrm{N}_{2} \mathrm{O}$ emission rate and the feeding type was found (Spearman coefficient of $\mathrm{R}=$ $-0.135, \mathrm{p}=0.581$ ).

The importance of the species trait Exoskeletal biofilm was further highlighted by the comparison of the $\mathrm{N}_{2} \mathrm{O}$ emission rates of the snail Hinia reticulata, which were measured both with the natural biofilm on the surface of the shell and with cleaned shell surfaces. The snails with an exoskeletal biofilm emitted more $\mathrm{N}_{2} \mathrm{O}$ than the cleaned individuals during the incu- 


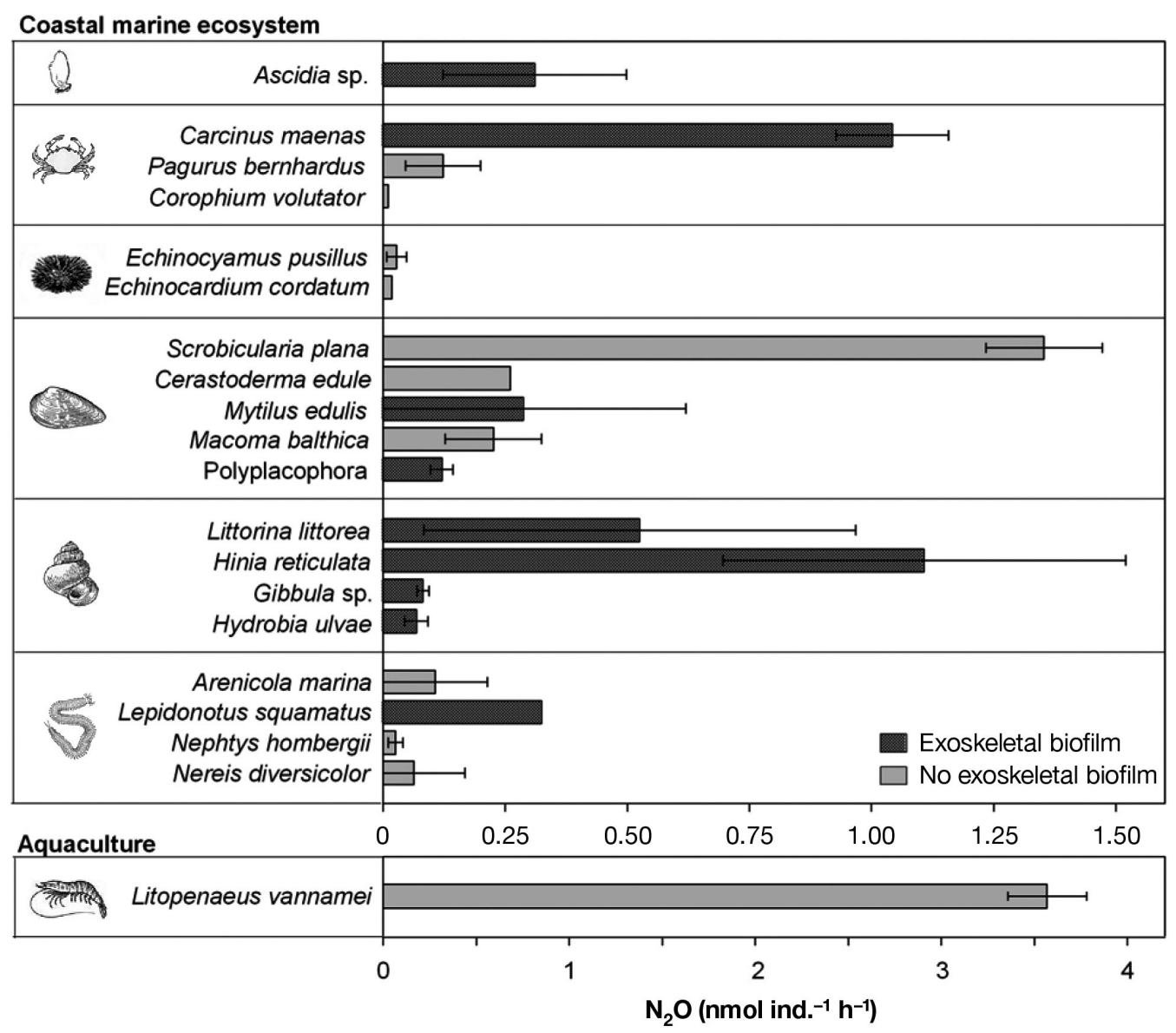

Fig. 1. Potential $\mathrm{N}_{2} \mathrm{O}$ emission rates of various marine invertebrate taxa. Individuals were incubated in gas-tight vials under oxic conditions at $21^{\circ} \mathrm{C}$, and $\mathrm{N}_{2} \mathrm{O}$ emission was analyzed by gas chromatograph measurements over 4 to $6 \mathrm{~h}$. Species are sorted by descending weight within each taxonomic group. Data are mean \pm SD for species with at least 3 replicates analyzed

bation period of $4.5 \mathrm{~h}$ (Fig. 3). The mean potential $\mathrm{N}_{2} \mathrm{O}$ emission rate of the biofilm-covered individuals (1.108 nmol ind. ${ }^{-1} \mathrm{~h}^{-1}$ ) was about 3.5 times higher than the rate of the cleaned individuals $\left(0.306 \mathrm{nmol}\right.$ ind. $^{-1}$ $\mathrm{h}^{-1}$ ). The mean potential $\mathrm{N}_{2} \mathrm{O}$ emission rates of biofilmcovered and cleaned individuals were assessed by a $t$-test and marginally failed significance with $\mathrm{p}=0.057$ $(t=-3.06 ; \mathrm{df}=2.92)$.

\section{DISCUSSION}

\section{Nitrous oxide emission potential}

The present study revealed that many coastal marine invertebrate species emit $\mathrm{N}_{2} \mathrm{O}$, representing a source that has been overlooked. The average potential $\mathrm{N}_{2} \mathrm{O}$ emission rate of 19 marine invertebrate species was $0.320 \mathrm{nmol}$ ind.$^{-1} \mathrm{~h}^{-1}$, excluding the aquacultured shrimp Litopenaeus vannamei, which had an exceptionally high rate. For 20 freshwater invertebrate species, an average potential $\mathrm{N}_{2} \mathrm{O}$ emission rate of only $0.072 \mathrm{nmol}$ ind. ${ }^{-1} \mathrm{~h}^{-1}$ was reported (Stief et al. 2009). In addition to the higher average rate, the $\mathrm{N}_{2} \mathrm{O}$ emission potential of marine invertebrates is apparently influenced by species-specific traits (i.e. body weight, habitat, and presence of an exoskeletal biofilm) that differ from those that influence the $\mathrm{N}_{2} \mathrm{O}$ emission potential of freshwater species (i.e. feeding type) (Stief et al. 2009).

\section{Correlation with species traits}

At a first glance, the positive correlation with body weight suggests that larger animals with presumably larger guts produce more $\mathrm{N}_{2} \mathrm{O}$ than smaller animals because of the larger number of microbes passing through their gut. This interpretation is consistent with the hypothesis that, in marine invertebrates, $\mathrm{N}_{2} \mathrm{O}$ production is also mediated by ingested microbes, as is the case for earthworms and freshwater invertebrates (Drake et al. 2006, Stief et al. 2009). 


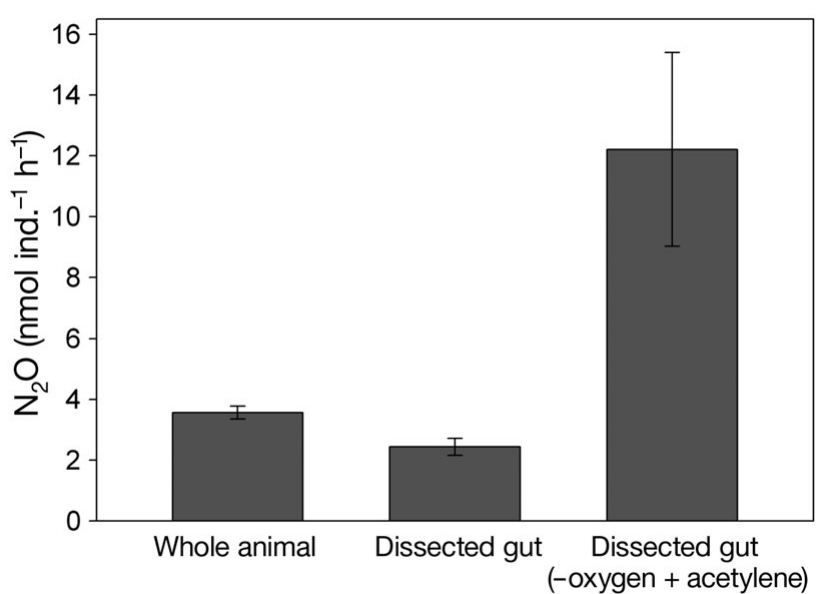

Fig. 2. Litopenaeus vannamei. Potential $\mathrm{N}_{2} \mathrm{O}$ emission rates (mean $\pm \mathrm{SD} ; \mathrm{n}=3$ to 6 ) of the shrimp $L$. vannamei and its dissected guts under oxic conditions at $21^{\circ} \mathrm{C}$. Dissected guts of $L$. vannamei were also incubated under anoxic conditions with $10 \%$ acetylene, which inhibits the last step of denitrification. The resulting $\mathrm{N}_{2} \mathrm{O}$ production indicates total denitrification

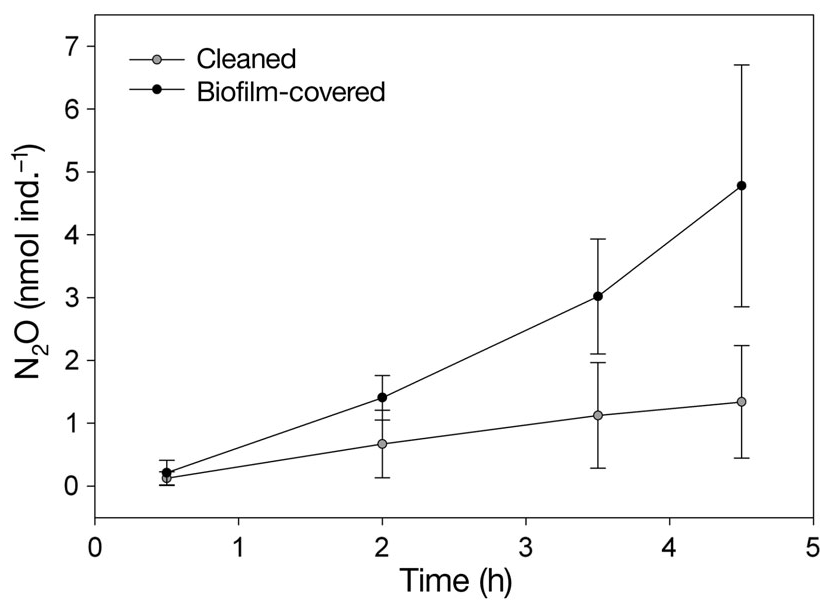

Fig. 3. Hinia reticulata. Potential $\mathrm{N}_{2} \mathrm{O}$ emission (mean $\pm \mathrm{SD}_{i}$ $\mathrm{n}=3$ ) by cleaned and biofilm-covered individuals of the snail $H$. reticulata during the incubation period of $4.5 \mathrm{~h}$

The correlation between potential $\mathrm{N}_{2} \mathrm{O}$ emission rate and the presence of an exoskeletal biofilm suggests that $\mathrm{N}_{2} \mathrm{O}$ production associated with marine invertebrates is not always due to denitrification in the gut (as proven for the shrimp Litopenaeus vannamei), but may also result from microbial activity on the external surfaces of the animal. Lower potential $\mathrm{N}_{2} \mathrm{O}$ emission rates of individuals of the snail Hinia reticulata with an experimentally cleaned shell surface further substantiate that $\mathrm{N}_{2} \mathrm{O}$ production is also linked to microbial activity in the exoskeletal biofilm. Furthermore, for this type of animal-associated $\mathrm{N}_{2} \mathrm{O}$ production, the shell of larger animals is presumably colonized with larger numbers of bacteria involved in $\mathrm{N}_{2} \mathrm{O}$ production, which is in line with the weight-dependence of $\mathrm{N}_{2} \mathrm{O}$ emission. The microbial pathway for biofilm-associated $\mathrm{N}_{2} \mathrm{O}$ production still needs to be identified. Depending on the oxygen availability inside the biofilm, nitrification or denitrification or both might contribute to the production of $\mathrm{N}_{2} \mathrm{O}$ (Meyer et al. 2008). Likewise, $\mathrm{N}_{2} \mathrm{O}$ production in the exoskeletal biofilm might be driven by ammonium from animal excretion or by nitrate from the water column, or by both. If an oxic-anoxic transition zone prevails in the biofilm, then nitrification and denitrification are probably coupled, as known for sediments in which denitrification is driven by nitrate from nitrification (Jenkins \& Kemp 1984). Thick biofilms were not established on the exoskeleton of every molluscan and crustacean species tested in the present study. The exoskeleton of Corophium volutator, Pagurus bernhardus, and L. vannamei, for instance, may not allow the formation of a persistent biofilm due to rather short time intervals between molting events, and the shells of infaunal molluscs (i.e. Macoma balthica, Cerastoderma edule, and Scrobicularia plana) may not be suitable for the formation of an exoskeletal biofilm due to physical abrasion in the sediment. It remains to be investigated whether certain freshwater invertebrate species have persistent biofilms on external surfaces of their body that produce $\mathrm{N}_{2} \mathrm{O}$.

Habitat (a proxy for nitrate availability in the immediate environment of the animal) was also significantly correlated with the $\mathrm{N}_{2} \mathrm{O}$ emission rate. The high potential emission rate of the epifaunal shrimp Litopenaeus vannamei, which is exposed to very high nitrate concentrations, agrees with this assumption. The effect of the habitat on $\mathrm{N}_{2} \mathrm{O}$ emission could be greater during autumn and winter, when nitrate concentrations in the water column at the 2 study sites are higher than in spring and summer (Kieskamp et al. 1991, Sømod 2005) and most of the animals studied are abundant and active.

$\mathrm{N}_{2} \mathrm{O}$ emission rate and species feeding type and diet were not correlated, which contrasts with the finding that $\mathrm{N}_{2} \mathrm{O}$ emission of freshwater invertebrates is dietdependent (Stief et al. 2009). Since marine species are usually larger and have longer guts and gut residence times than freshwater species (Bayne et al. 1987, Navarro et al. 1993), bacteria might be exposed long enough to anoxic conditions in the gut to express the full set of denitrification genes. In that case, complete denitrification will prevail and the main product will be dinitrogen rather than $\mathrm{N}_{2} \mathrm{O}$. Conversely, many of the ingested sediment bacteria might be efficiently digested in the gut of marine detritivorous species due to a high lysozyme activity (Plante \& Mayer 1994, 
Lucas \& Bertru 1997), which inhibits microbial $\mathrm{N}_{2} \mathrm{O}$ production. Lysozyme activity of dissected guts was approximately 5 times higher for the ragworm Nereis diversicolor (a marine non-emitter) than for the mayfly larva Ephemera danica (a freshwater emitter) (P. Stief unpubl. data).

\section{Ecosystem perspective}

Many species that tested positive for $\mathrm{N}_{2} \mathrm{O}$ emission in the present study are very abundant in coastal softbottom habitats; Macoma balthica and Cerastoderma edule can reach densities of 1000 ind. $\mathrm{m}^{-2}$ (Fujii 2007), Scrobicularia plana, 250 ind. $\mathrm{m}^{-2}$ (Cabral \& Murta 2004), and Arenicola marina, 100 ind. $\mathrm{m}^{-2}$ (Flach \& Beukema 1994). The mud snail Hydrobia ulvae can reach densities of up to 100000 ind. $\mathrm{m}^{-2}$ in intertidal sediments (Barnes 1999). This epifaunal species emits $\mathrm{N}_{2} \mathrm{O}$ directly into the water column or the atmosphere without diffusion through the sediment, as it lives at the sediment surface where it can be exposed to high nitrate concentrations and temperatures. Taking its potential $\mathrm{N}_{2} \mathrm{O}$ emission rate of $0.068 \mathrm{nmol}$ ind..$^{-1} \mathrm{~h}^{-1}$, this small snail could emit $6.8 \mu \mathrm{mol} \mathrm{N}_{2} \mathrm{O} \mathrm{m}^{-2} \mathrm{~h}^{-1}$, which is on the same order of magnitude as the benthic $\mathrm{N}_{2} \mathrm{O}$ fluxes reported for estuarine intertidal sediments (Middelburg et al. 1995) and intertidal rocky biofilms (Magalhaes et al. 2005).

For infaunal species, extrapolations are less robust because $\mathrm{N}_{2} \mathrm{O}$ conversion may take place inside the burrows of animals (Stief \& Schramm 2010). $\mathrm{N}_{2} \mathrm{O}$ produced by certain infaunal species is partially consumed while diffusing towards the sediment surface (Meyer et al. 2008), whereas other infaunal species increase benthic $\mathrm{N}_{2} \mathrm{O}$ flux more by their bioirrigation activity than by stimulating $\mathrm{N}_{2} \mathrm{O}$ production in their gut or in exoskeletal biofilms (Stief \& Schramm 2010). A second difficulty in scaling up animal-associated $\mathrm{N}_{2} \mathrm{O}$ production to ecosystem level lies in the discrepancy between potential and in situ rates. The contribution of animal-associated $\mathrm{N}_{2} \mathrm{O}$ production to overall benthic $\mathrm{N}_{2} \mathrm{O}$ emission can be better estimated from rate measurements made at different times of the year at the prevailing environmental conditions (Stief et al. 2010, Stief \& Schramm 2010). A rather constant $\mathrm{N}_{2} \mathrm{O}$ emission rate can be expected for the aquacultured species Litopenaeus vannamei, since it is exposed to the same conditions throughout the year. Given its very high potential $\mathrm{N}_{2} \mathrm{O}$ emission rate and the high growth rates of the aquaculture industry, $\mathrm{N}_{2} \mathrm{O}$ emission by other cultured species should be investigated.

Conceptually, $\mathrm{N}_{2} \mathrm{O}$ production associated with marine and freshwater invertebrates constitutes a link between reactive nitrogen (i.e. nitrate and ammonium) in aquatic ecosystems and $\mathrm{N}_{2} \mathrm{O}$ in the atmosphere that has been overlooked. Aquatic invertebrates complement the known sites of $\mathrm{N}_{2} \mathrm{O}$ production in the sediment with 3 additional microsites of $\mathrm{N}_{2} \mathrm{O}$ production: (1) the anoxic gut, a transient microbial habitat in which denitrification prevails (Stief et al. 2009); (2) the burrow, a microbial habitat with fluctuating conditions in which nitrification and denitrification co-occur (Svensson 1998); and (3) the exoskeletal biofilm, a microbial habitat with a yet unknown microenvironment in which nitrification and/or denitrification may occur (present study). The environmental controls of sedimentary and animal-associated $\mathrm{N}_{2} \mathrm{O}$ production may be similar (e.g. higher $\mathrm{N}_{2} \mathrm{O}$ production rates at higher temperature and nitrate or ammonium concentrations) and require further investigation.

Acknowledgements. We thank Hans Brix for providing the gas chromatograph. We are grateful for the help and assistance of Torben Vang and Leif Flensborg, the crew of the research vessel 'Genetica II' (Aarhus University). This research was supported by the Max Planck Society, the Danish Research Council and the German Science Foundation (STI202/6).

\section{LITERATURE CITED}

Bange HW (2006) New directions: the importance of oceanic nitrous oxide emissions. Atmos Environ 40:198-199

Barnes RSK (1999) What determines the distribution of coastal hydrobiid mudsnails within north-western Europe? PSZN I: Mar Ecol 20:97-110

Bayne BL, Hawkins AJS, Navarro E (1987) Feeding and digestion by the mussel Mytilus edulis L. (Bivalvia: Mollusca) in mixtures of silt and algal cells at low concentrations. J Exp Mar Biol Ecol 111:1-22

Bonin P, Raymond N (1990) Effects of oxygen on denitrification in marine sediments. Hydrobiologia 207:115-122

Braman RS, Hendrix SA (1989) Nanogram nitrite and nitrate determination in environmental and biological materials by Vanadium(III) reduction with chemi-luminescence detection. Anal Chem 61:2715-2718

> Cabral HN, Murta AG (2004) Effect of sampling design on abundance estimates of benthic invertebrates in environmental monitoring studies. Mar Ecol Prog Ser 276:19-24

Dong LF, Nedwell DB, Underwood GJC, Thornton DCO, Rusmana I (2002) Nitrous oxide formation in the Colne estuary, England: the central role of nitrite. Appl Environ Microbiol 68:1240-1249

> Drake HL, Horn MA (2007) As the worm turns: the earthworm gut as a transient habitat for soil microbial biomes. Annu Rev Microbiol 61:169-189

Drake HL, Schramm A, Horn MA (2006) Earthworm gut microbial biomes: their importance to soil microorganisms, denitrification, and the terrestrial production of the greenhouse gas $\mathrm{N}_{2} \mathrm{O}$. In: König $\mathrm{H}$, Varma A (eds) Soil biology, Vol 6. Intestinal microorganisms of soil invertebrates. Springer-Verlag, Heidelberg, p 65-87

> Ferrón S, Alonso-Pérez F, Anfuso E, Murillo FJ, Ortega T, Castro CG, Forja JM (2009) Benthic nutrient recycling on the northeastern shelf of the Gulf of Cádiz (SW Iberian Peninsula). Mar Ecol Prog Ser 390:79-95 
Flach EC, Beukema JJ (1994) Density-governing mechanisms in populations of the lugworm Arenicola marina on tidal flats. Mar Ecol Prog Ser 115:139-149

Fujii T (2007) Spatial patterns of benthic macrofauna in relation to environmental variables in an intertidal habitat in the Humber Estuary, UK: developing a tool for estuarine shoreline management. Estuar Coast Shelf Sci 75:101-119

Goreau TJ, Kaplan WA, Wofsy SC, McElroy MB, Valois FW, Watson SW (1980) Production of $\mathrm{NO}_{2}{ }^{-}$and $\mathrm{N}_{2} \mathrm{O}$ by nitrifying bacteria at reduced concentrations of oxygen. Appl Environ Microbiol 40:526-532

IPCC (Intergovernmental Panel on Climate Change) (2007) Climate Change 2007. The physical science basis-summary for policy makers. Cambridge University Press, Cambridge

Jenkins MC, Kemp WM (1984) The coupling of nitrification and denitrification in two estuarine sediments. Limnol Oceanogr 29:609-619

Kach DJ, Ward JE (2008) The role of marine aggregates in the ingestion of picoplankton-size particles by suspensionfeeding mollusks. Mar Biol 153:797-805

Karsten GR, Drake HL (1997) Denitrifying bacteria in the earthworm gastrointestinal tract and in vivo emission of nitrous oxide $\left(\mathrm{N}_{2} \mathrm{O}\right)$ by earthworms. Appl Environ Microbiol 63:1878-1882

Kieskamp WM, Lohse L, Epping E, Helder W (1991) Seasonal variation in denitrification rates and nitrous oxide fluxes in intertidal sediments of the western Wadden Sea. Mar Ecol Prog Ser 72:145-151

Law CS, Rees AP, Owens NJP (1992) Nitrous oxide-estuarine sources and atmospheric flux. Estuar Coast Shelf Sci 35:301-314

> Lucas F, Bertru G (1997) Bacteriolysis in the gut of Nereis diversicolor (O.F. Muller) and effect of the diet. J Exp Mar Biol Ecol 215:235-245

Magalhaes CM, Wiebe WJ, Joye SB, Bordalo A (2005) Inorganic nitrogen dynamics in intertidal rocky biofilms and sediments of the Douro River estuary (Portugal). Estuaries 28:592-607

> Magalhaes C, Costa J, Teixeira C, Bordalo AA (2007) Impact of trace metals on denitrification in estuarine sediments of the Douro River estuary, Portugal. Mar Chem 107:332-341

Matthies C, Griesshammer A, Schmittroth M, Drake HL (1999) Evidence for involvement of gut-associated denitrifying bacteria in emission of nitrous oxide $\left(\mathrm{N}_{2} \mathrm{O}\right)$ by earthworms obtained from garden and forest soils. Appl Environ Microbiol 65:3599-3604

McHenery JG, Birkbeck TH (1985) Uptake and processing of cultured microorganisms by bivalves. J Exp Mar Biol Ecol 90:145-163

Meyer RL, Allen DE, Schmidt S (2008) Nitrification and denitrification as sources of sediment nitrous oxide production: a microsensor approach. Mar Chem 110:68-76

Middelburg JJ, Klaver G, Nieuwenhuize J, Markusse RM, Vlug T, Vandernat F (1995) Nitrous oxide emissions from estuarine intertidal sediments. Hydrobiologia 311:43-55

Mosier A, Kroeze C, Nevison C, Oenema O, Seitzinger S, Van Cleemput O (1998) Closing the global $\mathrm{N}_{2} \mathrm{O}$ budget: nitrous oxide emissions through the agricultural nitrogen cycleOECD/IPCC/IEA Phase II development of IPCC guidelines for national greenhouse gas inventory methodology. Nutr Cycl Agroecosyst 52:225-248

Navarro E, Iglesias JIP, Ortega MM, Larretxea X (1993) The

Editorial responsibility: Ronald Kiene,

Mobile, Alabama, USA basis for a functional response to variable food quantity and quality in cockles Cerastoderma edule (Bivalvia, Cardiidae). Physiol Zool 67:468-496

Philippart CJM, Beukema JJ, Cadee GC (2007) Impacts of nutrient reduction on coastal communities. Ecosystems 10: 96-118

> Plante CJ, Mayer LM (1994) Distribution and efficiency of bacteriolysis in the gut of Arenicola marina and three additional deposit feeders. Mar Ecol Prog Ser 109:183-194

Ravishankara AR, Daniel JS, Portmann RW (2009) Nitrous oxide $\left(\mathrm{N}_{2} \mathrm{O}\right)$ : the dominant ozone-depleting substance emitted in the 21st century. Science 326:123-125

Robinson AD, Nedwell DB, Harrison RM, Ogilvie BG (1998) Hypernutrified estuaries as sources of $\mathrm{N}_{2} \mathrm{O}$ emission to the atmosphere: the estuary of the River Colne, Essex, UK. Mar Ecol Prog Ser 164:59-71

Seitzinger SP (1988) Denitrification in freshwater and coastal marine ecosystems: ecological and geochemical significance. Limnol Oceanogr 33:702-724

> Seitzinger SP, Kroeze C (1998) Global distribution of nitrous oxide production and inputs in freshwater and coastal marine ecosystems. Global Biogeochem Cycles 12:93-113

> Seitzinger SP, Nixon SW (1985) Eutrophication and the rate of denitrification and $\mathrm{N}_{2} \mathrm{O}$ production in coastal marine sediments. Limnol Oceanogr 30:1332-1339

Sømod B (2005) Århus Bugt Tilstand og udvikling 2004 (Aarhus Bay state and development 2004). Aarhus Amt Natur and Miljø, Højbjerg

> Sørensen J (1978) Denitrification rates in a marine sediment as measured by the acetylene inhibition technique. Appl Environ Microbiol 36:139-143

Stein LY, Yung YL (2003) Production, isotopic composition, and atmospheric fate of biologically produced nitrous oxide. Annu Rev Earth Planet Sci 31:329-356

Stief P, Schramm A (2010) Regulation of nitrous oxide emission associated with benthic invertebrates. Freshw Biol 55: $1647-1657$

> Stief P, Poulsen M, Nielsen LP, Brix H, Schramm A (2009) Nitrous oxide emission by aquatic macrofauna. Proc Natl Acad Sci USA 106:4296-4300

Stief P, Polerecky L, Poulsen M, Schramm A (2010) Control of nitrous oxide emission from Chironomus plumosus larvae by nitrate and temperature. Limnol Oceanogr 55:872-884

Svensson JM (1998) Emission of $\mathrm{N}_{2} \mathrm{O}$, nitrification and denitrification in a eutrophic lake sediment bioturbated by Chironomus plumosus. Aquat Microb Ecol 14:289-299

Tiedje JM (1988) Ecology of denitrification and dissimilatory nitrate reduction to ammonium. Biology of anaerobic microorganisms. Wiley, New York, p 179-244

> Van Beusekom JEE, Weigelt-Krenz S, Martens P (2008) Longterm variability of winter nitrate concentrations in the northern Wadden Sea driven by freshwater discharge, decreasing riverine loads and denitrification. Helgol Mar Res 62:49-57

- Weiss RF, Price BA (1980) Nitrous oxide solubility in water and seawater. Mar Chem 8:347-359

- Williams ID, Van der Meer J, Dekker R (2004) Exploring interactions among intertidal macrozoobenthos of the Dutch Wadden Sea using population growth models. J Sea Res 52:307-319

> Zumft WG (1997) Cell biology and molecular basis of denitrification. Microbiol Mol Biol Rev 61:533-616

Submitted: January 15, 2010; Accepted: July 7, 2010

Proofs received from author(s): September 10, 2010 